\title{
Canadian Urological Association guideline on male urethral stricture
}

\author{
Keith F. Rourke ${ }^{1}$; Blayne Welk ${ }^{2}$; Ron Kodama ${ }^{3}$; Greg Bailly ${ }^{4}$; Tim Davies ${ }^{5}$; Nancy Santesso ${ }^{5}$; \\ Philippe D. Violette ${ }^{5}$ \\ ${ }^{1}$ Division of Urology, University of Alberta, Edmonton, AB, Canada; ${ }^{2}$ Division of Urology, Western University, \\ London, ON, Canada; ${ }^{3}$ Division of Urology, University of Toronto, Toronto, ON, Canada; ${ }^{4}$ Department of Urology, \\ Dalhousie University, Halifax, NS, Canada; ${ }^{5}$ McMaster University, Hamilton, ON, Canada
}

Cite as: Can Urol Assoc J 2020 June 17; Epub ahead of print. http://dx.doi.org/10.5489/cuaj.6792

Published online June 17, 2020

$* * *$

\begin{abstract}
Urethral stricture is fundamentally a fibrosis of the urethral epithelial and associated corpus spongiosum which in turn causes obstruction of the urethral lumen. Patients with urethral stricture most commonly present with lower urinary tract symptoms, urinary retention or urinary tract infection but may also experience a broad spectrum of other signs and symptoms including genitourinary pain, hematuria, abscess, ejaculatory dysfunction, or renal failure. When urethral stricture is initially suspected based on clinical assessment, cystoscopy is suggested as the modality that most accurately establishes the diagnosis. This recommendation is based on several factors including the accuracy of cystoscopy as well as its wide availability, lesser overall cost, and comfort of urologists with this technique. When recurrent urethral stricture is suspected, we suggest performing retrograde urethrography to further stage the length and location of the stricture or referring the patient to a physician with expertise in reconstructive urology. Ultimately, the treatment decision depends on several factors, including the type and acuity of patient symptoms, the presence of complications, prior interventions, and the overall impact of the urethral stricture on the patient's quality of life. Endoscopic treatment either as dilation or internal urethrotomy is suggested rather than urethroplasty for the initial treatment of urethral stricture. This recommendation applies to men with undifferentiated urethral stricture and does not apply to trauma-related urethral injuries, penile urethral strictures (hypospadias, lichen sclerosus) or suspected urethral malignancy. In the setting of recurrent urethral stricture, urethroplasty is suggested rather than repeat endoscopic management but this may vary depending on patient preference and impact of the symptoms on the patient.
\end{abstract}




\section{Purpose}

The purpose of this guideline is to provide a practical summary outlining the diagnosis and treatment of urethral stricture in the Canadian setting.

\section{Introduction, epidemiology, and etiology}

Urethral stricture is likely the oldest urologic disease with documentation of its existence over 4000 years ago. ${ }^{1}$ The prevalence has likely changed over the course of human history. In the $19^{\text {th }}$ century it was thought that up to $20 \%$ of adult men developed urethral stricture. ${ }^{2}$ Currently the prevalence of urethral stricture may vary widely throughout the globe but in industrialized nations is reported to be approximately $0.9 \%$ based on epidemiologic data. ${ }^{3}$ Fundamentally urethral stricture is a fibrosis of the urethral epithelial tissue and corpus spongiosum which in turn causes narrowing of the urethral lumen. ${ }^{4}$ By convention when located in the anterior urethra the term stricture is used but when located in the posterior urethra the term stenosis is most appropriate. ${ }^{5}$ As the urethral lumen progressively narrows, varying degrees of obstruction occur.

Urethral strictures can occur as a result of one of two general mechanisms. Injury to the outside of the spongiosum, leading to spongiofibrosis, can occur as a result of blunt or penetrating trauma. Alternatively, instrumentation or inflammatory disease can cause internal disruption of the urethral epithelium also leading to spongiofibrosis. In general, the etiology of stricture is categorized into iatrogenic, idiopathic, traumatic, congenital and inflammatory causes. ${ }^{6}$ Etiologies within these categories are broad, and include instrumentation (e.g. cystoscopy), TURP, indwelling catheter, treatment for prostate cancer, straddle injury, lichen sclerosis, and post-infectious strictures.

While not explicitly a cause of stricture, other epidemiologic factors are associated with an increased likelihood of developing a urethral stricture. The likelihood of being diagnosed with a urethral stricture increases with age. For example, men aged 55-64 are 1.5 times more likely to have urethral stricture compared to controls under 55 years of age with a steady increase in incidence throughout each subsequent decade peaking with a 12-fold risk in men over the age of 85. ${ }^{4}$ There also appears to be an increased likelihood of developing a urethral stricture with declining socioeconomic status. ${ }^{4}$

Globally, urethral stricture accounts for a substantial amount of inpatient, ambulatory and emergency room visits. ${ }^{4}$ Accordingly, urethral stricture incurs a yearly individual average cost of disease estimated at $\$ 6000$ with a total estimated cost of over $\$ 200$ million per year in the United States independent of reduced patient quality of life. ${ }^{4,7}$

\section{GRADE methodology}

This guideline was developed using the Grading of Recommendations Assessment, Development and Evaluation (GRADE) Adolopment approach. ${ }^{8}$ We established a guideline panel with 5 members with expertise in urology, urological surgery, reconstructive urology and guideline 
methodology. No panel member was identified to have conflicts of interest limiting their participation on this panel.

In August 2018, the panel prioritised three key questions to address in this guideline related to the identification of urethral stricture and its treatment. The panel also identified the critical outcomes on which the recommendations were made: stricture recurrence, improvement in lower urinary tract symptoms, quality of life, additional procedures, and stricture related complications. The methodology team from Cochrane Canada conducted a comprehensive search of the literature for published systematic reviews and reviews published in clinical practice guidelines that addressed the key questions. We identified a guideline published by the American Urological Association (AUA) in which the evidence was reviewed up to January 2015. ${ }^{9}$

The search of the AUA review was updated from January 2014 to October 2018 in Medline, Embase and Central and identified 1429 citations. Citations were subsequently screened by members of the guideline panel and the Cochrane Canada team for comparative studies and studies evaluating the effects of one intervention or test, or studies addressing factors such as patient values and preferences, resources, equity, acceptability or feasibility. When possible, comparative data and a calculated risk ratio was pooled using RevMan 5.2. Data from studies evaluating one intervention were pooled using an unweighted average. For recommendation 1, evidence was synthesized from six studies for test accuracy of retrograde urethrogram (RUG) or sonourethrogram (SUG) previously identified in the AUA review; for recommendation 2, six studies from the AUA review and 22 new studies were synthesized; and, for recommendation 3, 11 from the AUA review and 21 new studies were synthesised (see Appendix for syntheses and references to included studies). The risk of bias of the studies and the certainty of the evidence were assessed using the GRADE approach. ${ }^{10-16}$ The evidence was presented in evidence profiles and Evidence to Decision Tables using GRADEpro (See Appendix).

The guideline panel developed the recommendations by consensus during two teleconference meetings. The panel considered the desirable and undesirable effects of the interventions, the value placed on the outcomes, the required resources, the acceptability of the interventions to all stakeholders, the impact on health equity, and the feasibility of the interventions. The strength of each recommendation was rated as either strong or conditional. Strong recommendations were made when all the desirable consequences of treatment outweighed the undesirable consequences, and are worded as "recommends". Conditional recommendations were made when the desirable consequences probably outweighed the undesirable consequences, and are worded as "suggests" (see Table 1). The final recommendations were reviewed and approved by the guideline panel. 


\section{Presentation and assessment}

\section{Signs and symptoms}

Regardless of the mechanism or injury, as the scar tissue contracts, there is generally a reduction in the caliber of the urethral lumen. Most of the symptoms related to urethral stricture are thought to be directly related to this decrease in urethral caliber. Typical symptoms include lower urinary tract symptoms (LUTS) such as weak urinary stream, straining to void, urinary hesitancy, nocturia, frequency and the sensation of incomplete emptying. ${ }^{17}$ Other signs and symptoms such as genitourinary pain, urinary tract infection, ejaculatory dysfunction, urethral discharge and hematuria may also occur. A significant proportion of patients with urethral stricture will experience significant complications requiring emergent urologic care including acute urinary retention, urinary tract infection, difficult catheterization, renal failure, or peri-urethral abscess. ${ }^{18}$ Additionally, some of these complications can be considered life threatening. For example, urethral stricture is a known risk factor for Fournier's gangrene.

\section{Assessment}

Patients suspected of having a urethral stricture should be evaluated with history, physical examination, serum creatinine and urinalysis. The initial evaluation may also include a combination of patient reported measures such as the International Prostate Symptom Score (IPSS), uroflowmetry, and ultrasound post-void residual urine measurement. When a stricture is suspected, cystourethroscopy or retrograde urethrography have been historically utilized to confirm the diagnosis. Ancillary investigative tools used in special circumstances include urethral ultrasonography and magnetic resonance imaging.

\section{Diagnosis: should men with suspected urethral stricture undergo cystoscopy as the most accurate method to diagnose a clinically significant urethral stricture?}

Recommendations: We suggest using cystoscopy rather than urethrography for the initial diagnosis of suspected urethral stricture (Conditional recommendation, low certainty in evidence of effects). We suggest performing retrograde urethrography to further stage urethral stricture or referring the patient to a physician with expertise in reconstructive urology, when a recurrent stricture is suspected (Conditional recommendation, low certainty in evidence of effects). We suggest against using magnetic resonance imaging for routine initial diagnosis of suspected stricture (Conditional recommendation, low certainty in evidence of effects).

This recommendation is based on several factors including the accuracy of cystoscopy as well as its wide availability, lesser cost, and comfort of urologists with this technique. In this setting, literature review identified six studies that assessed retrograde urethrogram (RUG) and/or sonourethrogram (SUG) compared to cystoscopy with confirmation by surgery as the reference standard. ${ }^{19-24}$ Based on the literature, there is a lower certainty of evidence for the 
sensitivity and specificity of urethrography when using a prevalence of $60 \%$ urethral stricture in clinically suspected men. Ultimately, the use of urethrography at initial diagnosis likely leads to greater numbers of missed cases of urethral stricture ( 2 to 4 more per 100 men) and unnecessary treatment ( 0 to 6 more per 100 men) than when performing cystoscopy. Moreover, cystoscopy is widely available in most clinical settings, and requires fewer resources (such as costs, equipment and training) than urethrography with less radiation exposure (specific to RUGs). However, RUG over cystoscopy accurately determines urethral stricture location and length, which is of paramount importance especially when evaluating patients who are at risk of failure of endoscopic treatment such as in the setting of recurrent stricture, traumatic strictures, radiations stenoses, and stricture associated with hypospadias. Lastly, the benefits of using MRI were outweighed by the expense, lack of resources, and impracticality of MRI and could be best reserved for select cases including complex trauma (pelvic fracture urethral injury), suspected urethral malignancy, radiotherapy induced urethral stenosis or associated rectourethral fistula.

\section{Treatment options}

The decision to treat a urethral stricture depends on several factors, including symptoms and complications related to urethral stricture (urinary infection, pain, abscess, gross hematuria, renal dysfunction, urinary retention), prior interventions for urethral stricture disease, and the impact of the urethral stricture on the patient's quality of life.

Once diagnosed urologists can offer the patient urethral dilation, direct visual internal urethrotomy (DVIU), urethroplasty, or perineal urethrostomy for the treatment of urethral stricture.

One of the original (and still most frequent) treatments of urethral stricture disease is urethral dilation. It is an in-office treatment that can be performed either using urethral sounds, or using a wire plus either a balloon dilator or sequentially sized disposable dilators placed using a Seldinger technique. A direct vision internal urethrotomy (DVIU) is usually done in the operating room, and uses a urethrotome ("cold knife") or laser to incise through the scar. There is no evidence that DVIU is superior to dilation, or that any specific technical (for example laser versus cold knife incision) is superior; in general results are modest for well-selected strictures $(<1 \mathrm{~cm}$ bulbar strictures with minimal spongiofibrosis and $\leq 2$ prior dilations/incisions $){ }^{25}$ As initial treatment for patients with long $(\geq 2 \mathrm{~cm})$ bulbar urethral strictures, penile stricture or recurrent urethral stricture, endoscopic treatments typically have a low rate of success in the long-term. Likewise, after 2 failed endoscopic treatments, the chance of cure is essentially zero, and the procedure becomes a recurring, temporary management strategy.

Urethroplasty involves either anastomotic (complete surgical excision of the stricture with urethral re-anastomosis), or augmentation (tissue transfer to increase urethral caliber) techniques. Anastomotic urethroplasty is most appropriate for anterior urethral strictures where there is a relatively short stricture ( $<2 \mathrm{~cm}$ in length) in bulbar urethra. It has a very good success rate $(>90 \%)$, a low complication rate and potentially lower recurrence rate when compared to 
other urethroplasty techniques. ${ }^{26}$ The other common approach to urethroplasty involves the augmentation of the urethral lumen. This can be carried out using a variety of potential grafts (most commonly oral mucosal grafts) or genital (penile) fasciocutaneous flaps. There are a variety of technical considerations that go into selected an operative approach in these cases; in general both grafts and flaps have equivalent success rates, but flaps are associated with more morbidity. ${ }^{27}$ When tissue transfer is indicated most urologists performing urethroplasty use an oral mucosal graft as the primary tissue source. Allograft, xenograft, or synthetic materials should not be used to perform urethroplasty outside of study protocols. In patients with recurrent stricture who are not candidates for urethroplasty, self-catheterization after direct visual internal urethrotomy (DVIU) may help maintain urethral patency for longer periods. Perineal urethrostomy is also a long-term treatment option for patients as an alternative to urethroplasty. ${ }^{28}$

\section{Clinically important outcomes}

Treatment of a patient with urethral stricture involves consideration of several potentially important outcomes including the degree, acuity and type of symptoms as well as associated complications, risks of treatment and patient preference. Clinically important outcomes for this guideline were determined using a combination of expert opinion and existing literature on patient preference. ${ }^{29,30}$ Given that the majority of patients with urethral stricture experience lower urinary tract symptoms (LUTS) or urinary retention as a consequence of urethral stricture, improvement in LUTS or avoidance of urinary retention is undoubtedly an important outcome. ${ }^{17}$ In addition to LUTS, patients may also experience sexual dysfunction and/or genitourinary pain related to urethral stricture or as a consequence of treatment. Given the broad spectrum of signs and symptoms, improvement in health-related quality of life is important to consider. While most patients experience symptoms, many may also experience complications due to stricture or treatment. Lastly, the need for repeated lifelong procedures requires some consideration in the decision-making process. The clinical outcomes determined to be most important based on the committee's opinion and reviewed literature are listed in Table 3 in order of decreasing importance.

\section{Initial treatment: Should endoscopic management (dilation or direct vision internal urethrotomy) compared to urethroplasty be used for men with the initial diagnosis of urethral stricture?}

Recommendation: We suggest endoscopic management as the initial treatment of the symptomatic undifferentiated stricture (Conditional Recommendation, Low levels of certainty of evidence).

To generate this recommendation the evidence from the AUA guideline was updated from 2014 to $2018 . .^{9}$ There were 28 relevant non-randomized studies with five comparing 
endoscopic management to urethroplasty. ${ }^{31-58}$ Table 4 outlines stricture recurrence rates and other outcomes amongst non-randomized non-comparative studies stratified by procedure. After incorporation into our evidence to decision framework it was determined that in men initially presenting with symptomatic urethral strictures, direct visual internal urethrotomy (DVIU) or urethral dilation, can be performed prior to offering urethroplasty. This recommendation does not apply to those patients with strictures that have a high rate of recurrence from endoscopic treatment. These complex cases include strictures from failed hypospadias repairs, penile urethral strictures, lichen sclerosis related strictures, trauma related urethral strictures, strictures longer than $2 \mathrm{~cm}$, and those with a completely obliterated lumen. Primary urethral cancer is a rare malignancy often presenting with locally advanced disease. Patients with suspected urethral malignancy should be diagnosed with biopsy and managed appropriately. ${ }^{59}$

The justification for this PICO recommendation is based on low levels of certainty. Overall, recurrence rates are moderately in favour of urethroplasty over endoscopic treatments ( $15.5 \%$ versus $38.5 \%$ respectively) in this setting. For those complications with data available in both treatment groups, including other urinary, infection, bleeding and other complications, the risk was at least $4 \%$ greater with urethroplasty than endoscopic management (Table 5). No direct cost effectiveness studies were identified in this specific instance. However, with the lower recurrence rates, the initial cost of urethroplasty may be similar or outweigh the cost of repeated endoscopic treatments. Endoscopic management is in every urologist's armamentarium and therefore is widely available and accessible as compared to surgeons trained in urethral reconstruction. Lastly, patient's preference may initially lean toward minimally invasive techniques prior to reconstruction.

\section{Recurrent stricture: Should urethroplasty compared to endoscopic treatment (either dilation or dviu) be used for men with recurrent urethral stricture?}

Recommendation: In the setting of men with recurrent urethral stricture failing prior endoscopic treatment, we suggest performing urethroplasty rather than repeat endoscopic management (DVIU or dilation) (Conditional recommendation, very low certainty in evidence of effects).

For this specific PICO question, no randomized controlled trials (RCTs) were identified comparing urethroplasty to endoscopic treatment (either dilation or DVIU) for men with recurrent urethral stricture. One comparative study ${ }^{60}$ and 31 noncomparative studies $44,48,51,61-88$ were identified including 21 studies assessing urethroplasty ${ }^{62,64-68,70-74,76,79-87}$ and 10 studies assessing endoscopic treatment. $44,48,51,61,63,69,75,77,78,88$

In this specific setting, the benefits of urethroplasty are moderately greater than endoscopic management with an approximate $16 \%$ recurrence rate versus a greater than $50 \%$ rate of stricture recurrence ( $\sim 53 \%)$ (Table 6$)$. Both comparative studies and case series demonstrated higher rates of stricture recurrence with endoscopic management when compared to 
urethroplasty. Additionally, in studies that report details of previous treatment, repeat endoscopic treatment may increase stricture complexity, increase urethroplasty complexity and increase the rate of stricture recurrence with treatment. The symptomatic recurrence rate after endoscopic treatment may vary and depends on stricture etiology, location, length and the number of failed prior endoscopic treatments. While there may be similar initial rates of complications (26-27\%) over the long-term course of the disease, urethroplasty may offer a lower risk of complications than endoscopic management due to the cumulative rate of complications related to the need for repeat endoscopic treatments. Moreover, this does not take into account complications directly related to stricture only treatment related complications. Other factors such as cost, equity and patient preference play a role in determining the best course of treatment in this setting. The initial cost of urethroplasty may be moderately greater than endoscopic treatment but over the long-term with the subsequent risk of stricture recurrence, urethroplasty is typically more costeffective. While urethroplasty is less widely available than endoscopic treatment and requires additional training, it remains the preferred options when all outcomes are considered despite this difference in equity. When considering patient preference, most men who have multiple recurrences may prefer urethroplasty but a shared decision-making model will help to understand patients' values and preferences. Most men who have poor quality of life due to recurrent stricture will likely choose urethroplasty. Men who are frail with multiple co-morbidities, who want to avoid an in-hospital operative procedure, scheduling, timing or hospital stay, may choose DVIU or dilation for a recurrent stricture.

\section{Special circumstances}

While these guideline recommendations apply to the majority of patients presenting with urethral stricture, several etiologies and circumstances warrant specific mention.

\section{Trauma stenoses (pelvic fracture urethral injury, straddle trauma)}

The scope of this guideline is not intended to review the management of patients with acute anterior or pelvic fracture urethral injuries (PFUI). A Canadian review of the subject has been published recently. ${ }^{89}$ In general, the initial management of PFUI remains controversial. Options include suprapubic tube insertion or primary endoscopic realignment (retrograde or antegrade). Regardless of initial treatment, the majority of patients after pelvic fracture will develop urethral stenosis. It is recommended that this resultant PFUI related urethral stenosis be treated with delayed urethral reconstruction. Endoscopic maneuvers including "cut to the light" should be avoided since they usually do not result in a durable response, delay the treatment course and may increase the complexity of the future repair. ${ }^{90}$ Reconstruction usually occurs at 3-6 months' post trauma. The vast majority of these stenoses can be repaired trans-perineally in a single-stage operation with a high degree of success $(>90 \%)$. Maneuvers to bridge the gap include urethral mobilization, development of the intra-crural space, infra-pubectomy and rerouting the urethra around the corporal body. 
Patients who suffer a "straddle" urethral injury to the bulbar can be initially managed with catheter realignment or insertion of a suprapubic catheter. Catheter realignment however may increase the rate of stricture development. ${ }^{88,91}$ The mechanism of injury to the bulbar urethra is a compression type of force of the urethra against the pubis. This results in a transmural injury to the corpus spongiosum. ${ }^{92}$ Patients with a resultant symptomatic urethral stricture after a straddle injury likely are best treated with urethroplasty since urethral pathology reveals extensive fibrosis of the corpus spongiosum. Commonly this can be done with an excision and primary anastomosis. Because of this fibrosis, repeated endoscopic dilations or DVIUs are usually unsuccessful and may increase the complexity of the repair including the need for tissue transfer techniques. ${ }^{88,91}$

\section{Hypospadias-associated urethral strictures (HAUS)}

Urethral stricture is one the most common problems encountered in patients with hypospadias presenting as adults. ${ }^{93-96}$ Hypospadias is the most common cause of iatrogenic stricture in men under the age of 45 and may occur in up to $10 \%$ of patients with hypospadias. ${ }^{93,97}$ Development of stricture may be related to the use of preputial flaps, tubularized tissue, or proximal hypospadias. ${ }^{98}$ Patients often present insidiously with a longstanding history of LUTS, episodic UTI and/or acute urinary retention. There are several unique considerations when treating patients with hypospadias associated urethral stricture (HAUS). These patients often present with multiple associated problems, including LUTS (even in the absence of stricture) (50-82\%), urethrocutaneous fistula (16\%-30\%), persisting hypospadias (14-43\%), penile curvature (14\%$24 \%$ ), UTI (15-25\%), lichen sclerosus (8-43\%) or genitourinary pain (10\%). ${ }^{93,99-103}$ Patients frequently have a history multiple previous surgeries. ${ }^{93,99-103}$ Accordingly, physical examination is abnormal with attenuation of the glans, glans cleft, and ventral Dartos with visible scarring and fibrosis. Assessment with flexible cystoscopy or urethrography can be challenging owing to an abnormally situated or stenotic meatus. Use of a pediatric cystoscope or ureteroscope in this setting can be useful in evaluating the urethra with minimal manipulation. Urethral stricture in adult patients with hypospadias can also be difficult to classify but generally speaking fall into one of 4 categories based on length, location, and previous surgeries. The first and most common is a long "pan-penile" stricture involving the majority of the penile urethra in the setting of previous (and often multiple) hypospadias surgery. The second group comprises a "junctional stricture" which is a stricture of variable length at the junction of previous hypospadias repair and native urethra. Patients may also develop an isolated bulbar urethral stricture after hypospadias repair. The last group is that of urethral stricture developing in the setting of previously untreated hypospadias. ${ }^{104}$

Endoscopic treatments (dilation or urethrotomy) in most instances offers little chance of cure given that urethral dilation and urethrotomy are least successful in penile strictures and strictures greater than $2 \mathrm{~cm}$ in length, which is typical of hypospadias associated strictures. ${ }^{52}$ 
Treatment with urethroplasty can be successfully performed and is likely preferred especially in young adults but may vary depending on patient preference and expectations. In general, adult hypospadias surgery is frequently successful with reported "success" rates of 75-88\%. ${ }^{94,99-106}$ However, on average, 2 or more operations are required to treat HAUS and associated problems. ${ }^{94,102,105}$ Additionally, these surgeries incur a 26-68\% risk of complications likely because the ventral penile skin and Dartos fascia is deficient and poorly vascularized. ${ }^{94,99-106}$ Because of the potential complexity of urethroplasty in this population, perineal urethrostomy can also be a highly successful option for these patients who are either too unwell or unwilling to undergo urethroplasty.

\section{Bladder neck contracture (BNC)}

"Bladder neck contracture" (BNC) refers to the narrowing of the bladder neck following surgical treatment of bladder outlet obstruction (e.g. benign prostatic enlargement). BNC may occur following monopolar or bipolar transurethral resection of the prostate (TURP), or other energy sources of tissue ablation including photoselective vaporization of the prostate (PVP), holmium laser enucleation (HoLEP) or ablation of the prostate (HoLAP), and thulium vaporenucleation laser (Thu-VEP). The mechanism of and etiology of BNC is not clearly understood, but may be influenced by excessive resection and fulguration of the bladder neck and the hypertrophic scarring that results. The estimated incidence of BNC rages from 0 to $9.6 \%{ }^{107}$ The presentation of BNC often occurs within the first 6 months after prostate surgery, and may include both voiding and storage symptoms as with other urethral strictures. Risk factors for BNC include low adenoma weight, unmanaged pre-operative infections, long resection time, extensive resection of the bladder neck, diabetes, smoking, and cardiovascular disease. ${ }^{107}$ Once diagnosed, urethral dilation is often the first-line treatment in patients with a short BNC, although up to $90 \%$ may recur within the first 2 years. Other treatment options include bladder neck incision (BNI) using either a hot-knife, cold-knife, or laser technique although one method is not known to be superior over another. Self-calibration using in/out catheters may be a tool to stabilize the bladder neck following BNI. Techniques combining bladder neck ablation with transurethral injection of cytotoxic agents (e.g. mitomycin C) yield variable results but can be associated with significant complications including extravasation or bladder neck necrosis. Permanent suprapubic catheters or open reconstruction using $\mathrm{Y}-\mathrm{V}$ plasty techniques can be considered for recalcitrant BNC when repeated endoscopic attempts fail.

\section{Vesicourethral anastomotic stenosis (VUAS)}

Vesicourethral anastomotic stenosis (VUAS, or sometimes imprecisely also referred to as "bladder neck contracture") occurs in approximately 5-10\% of men after radical prostatectomy. ${ }^{108,109}$ The etiology is multifactorial, and likely is the result of both technical challenges at the time of prostatectomy, and adverse post-operative healing (such as postoperative hematoma or urine leak, or subsequent radiation therapy). In the setting of an 
asymptomatic VUAS, observation is appropriate as in some patients' the treatment of a VUAS results in de novo or worsening of urinary incontinence. ${ }^{110}$ Paradoxically, in some patients, treatment of the VUAS can actually improve post-prostatectomy incontinence by passively improving the coaptation of the external urethral sphincter. ${ }^{110}$ Patients who are symptomatic, or those who have a VUAS $<14$ French and are contemplating post-prostatectomy incontinence surgery should be treated initially with a urethral dilation or minimally invasive endoscopic procedures; often multiple procedures are necessary, but in most cases this is eventually successful. ${ }^{111}$ Usually a stepwise approach of a minimally traumatic urethral dilation, followed by a cold knife/electrocautery or laser incision of the stricture, and finally a deep incision or resection to the fat can be attempted, with success rates increasing with move invasive treatment methods. ${ }^{110,112}$ Endoscopic injection of steroid solution into the VUAS may improve patency, however the use of mitomycin appears to have a risk of serious adverse events. ${ }^{110,113}$ In cases where endoscopic interventions have failed, a tapering schedule of intermittent catheterization has been used to improve long-term patency rates. ${ }^{110}$ In rare cases open reconstruction may be contemplated, however this is a technically challenging procedure that will result in urinary incontinence that will almost certainly require the placement of an artificial urinary sphincter. While undertaking the treatment of VUAS, the physician should be aware of the rare but serious complication of fistulation to the pubic symphysis. ${ }^{114}$ This almost uniformly occurs in patients with a history of radiation therapy, and in many cases, develops after endoscopic procedures to treat VUAS. A patient will have severe pelvic pain, and an MRI of the pelvis should be done to confirm the diagnosis. Treatment of this complication usually requires a urinary diversion.

\section{Radiation-induced urethral stenoses}

Urethral stenosis is likely an under-recognized and under-reported complication of pelvic radiotherapy. ${ }^{108}$ Over time patients undergoing radiotherapy for prostate cancer have an almost 5-fold risk of developing urethral complications. ${ }^{108}$ After brachytherapy, the incidence of urethral stenosis is $1-8 \%$ and likely occurs more frequently in high dose protocols. ${ }^{115-120}$ After contemporary EBRT the incidence of posterior urethral stenosis is likely 2-4\%. ${ }^{108,121}$ Although urethral stenosis may occur within the first year after treatment, most patients typically present 57 years later. ${ }^{122-124}$ Rates of stenosis following combination modality EBRT/BT occur more frequently and are usually more complex. ${ }^{125}$ Treatment of radiotherapy induced urethral stenosis has not been well defined. ${ }^{108,119,121}$ Urethral stenosis after single modality radiation treatment typically occurs at the proximal bulbar urethra and extends to the membranous urethra with variable involvement of the prostatic apex. Radiation associated stenoses are usually refractory to endoscopic techniques. ${ }^{119}$ Urethroplasty, at least in properly selected patients with focal stenoses appears to be a reasonable option for patients failing endoscopic treatments with success rates reported between $69.7 \%-89.6 \% .^{122-124}$ The majority bulbomembranous stenoses after radiotherapy are amenable to anastomotic urethroplasty with tissue transfer reserved for strictures $>3 \mathrm{~cm}$ in length. However, even in well-selected patients, urethroplasty in a radiated 
field has risks related to compromised vascular supply, tissue necrosis, obliterated tissue planes, and fibroblast dysfunction potentially resulting in prolonged recovery and increased risk of complications. ${ }^{126,127}$

Bulbomembranous stenosis after radiation treatment is not typically an isolated problem and patients often have significant functional concerns both before and after treatment of urethral stenosis. Because of the field effect of radiation concurrent impairment in continence, erectile function and detrusor dysfunction is common. ${ }^{121-124}$ In these cases, return to "normal" urologic function is not a common occurrence. Additionally, because of the multi-focality of the problem and advanced patient age, some patients to prefer intermittent endoscopic treatment over more invasive treatments. Generally, patients with extensive prostate necrosis, cavitation, prostatosymphyseal fistula, osteomyelitis or a small functional bladder capacity are best served by urinary diversion in lieu of urethral reconstruction. ${ }^{19,121}$ However, in well selected and properly counselled patients with focal stenosis, urethral reconstruction is a viable option for establishing long-term urethral patency and improvement in lower urinary tract function.

\section{Lichen sclerosus}

Lichen sclerosus (LS) is a chronic, lymphocyte mediated skin disease; it was previously known as balanitis xerotica obliterans, but this is no longer the accepted term. It has an estimated prevalence of 1 in 300 men with a peak incidence in men aged 30-50 years. ${ }^{128}$ There is no proven etiology of LS but there have been theories tied to autoimmune conditions, hypogonadism, trauma, and genetics. There are documented associations with obesity, cardiovascular disease and cigarette use. ${ }^{128-130}$ LS is typically an insidious and progressive process that presents most commonly with phimosis, meatal stenosis (4 - 37\%) or urethral stricture (20-30\%). ${ }^{131}$ Ongoing surveillance is recommended due to potential association with the development of squamous cell carcinoma which can occur in $2-8 \%$ of men with lichen sclerosus. ${ }^{129}$

Treatment is predicated on the extent of the disease. Topical therapy is often employed in the form of topical corticosteroids such as clobetasol $(0.05 \%)$ or betamethasone $(0.05 \%)$ twice a day for 8-12 weeks. This results in an improvement in the cutaneous manifestations of LS in 40$90 \%$ of patients. LS involving the prepuce often requires surgical intervention for phimosis either dorsal slit or circumcision. When urethral stricture arises, the location, length and progression of LS associated stricture disease will guide treatment. Strictures related to LS tend to be progressive and it is important to counsel patients regarding the recalcitrant nature of LS related strictures. Stricture may present simply as isolated meatal stenosis and may respond to dilation with or without the use of intra-urethral steroid administration. ${ }^{132}$ Longer LS related strictures often require urethroplasty with tissue transfer for durable treatment success. Genital skin flaps and grafts should be avoided due to risk of LS related skin involvement. ${ }^{133}$ Oral mucosa tissue grafts are the gold standard treatment for LS related strictures. ${ }^{134,135}$ Single and multi-stage reconstructive approaches are well described and offer the best chance of success. 
Managing patient expectations is important with lichen sclerosus given that it is typically a recurrent and progressive condition. 


\section{References}

1. Das S. Shusruta of India, the pioneer in the treatment of urethral stricture. Surg Gynecol Obstet. 1983;157(6):581-582.

2. Arnott J. A treatise on stricture of the urethra. London: Burgess and Hill; 1819.

3. Anger JT BJ, Santucci RA, Elliott SP, Saigal CS. Urologic diseases in America project. Trends in stricture management among male Medicare beneficiaries: Underuse of urethroplasty? Urology. 2011;77(2):481-485.

4. Santucci RA JG, Wise M. Male urethral stricture disease In: Litwin MS SC, ed. Urologic Diseases in America. US Department of Health and Human Services, Public Health Service, National Institutes of Health, National Institute of Diabetes and Digestive and Kidney Diseases. Vol 5512. Washington, DC: US Government Printing Office; 2007:533-555.

5. Latini JM MJ, Brandes SB, Chung JY, Rosenstein D. SIU/ICUD consultation on urethral strictures: Epidemiology, etiology, anatomy, and nomenclature of urethral stenoses, strictures, and pelvic fracture urethral disruption injuries. Urology. 2014;83:S1-7.

6. Fenton AS MA, Aviles R, Garcia CR. Anterior urethral strictures: Etiology and characteristics. Urology. 2005;65(6):1055-1058.

7. Bullock TL BS. Adult anterior urethral strictures: A national practice patterns survey of board certified urologists in the United States. J Urology. 2007;177(2):685-690.

8. Schünemann HJ WW, Brozek J, Etxeandia-Ikobaltzeta I, Mustafa RA,, Manja V B-PR, Neumann I, Falavigna M, Alhazzani W, Santesso, N ZY, Meerpohl JJ, Morgan RL, Rochwerg B, Darzi A, Rojas MX, Carrasco-Labra, A AY, AlRayees Z, Riva J, Bollig C, Moore A, Yepes-Nuñez JJ, Cuello C, Waziry, R AE. GRADE Evidence to Decision (EtD) frameworks for adoption, adaptation, and de novo development of trustworthy recommendations: GRADE-ADOLOPMENT. J Clin Epidemiol. 2017;81:101-110.

9. Wessells H AK, Elliott S, Gonzalez CM, Kodama R, Peterson AC, Reston J, Rourke K, Stoffel JT, Vanni AJ, Voelzke BB, Zhao L, Santucci RA. Male urethral stricture: American Urological Association guideline. J Urology. 2017;197(1):182-190.

10. Balshem H HM, Schünemann HJ, Oxman AD, Kunz R, Brozek J, Vist GE, Falck-Ytter Y, Meerpohl J, Norris S, Guyatt GH. GRADE guidelines: 3. Rating the quality of evidence. J Clin Epidemiol. 2011;64(4):401-406.

11. Guyatt GH OA, Vist G, Kunz R, Brozek J, Alonso-Coello P, Montori V, Akl EA, Djulbegovic B, Falck-Ytter Y, Norris SL, Williams JW Jr, Atkins D, Meerpohl J, Schünemann HJ. GRADE guidelines: 4. Rating the quality of evidence--study limitations (risk of bias). J Clin Epidemiol. 2011;64(4):407-415.

12. Guyatt GH OA, Montori V, Vist G, Kunz R, Brozek J, Alonso-Coello P, Djulbegovic B, Atkins D, Falck-Ytter Y, Williams JW Jr, Meerpohl J, Norris SL, Akl EA, Schünemann HJ. GRADE guidelines: 5. Rating the quality of evidence--publication bias. J Clin Epidemiol. 2011;64(12):1277-1282.

13. Guyatt GH OA, Kunz R, Brozek J, Alonso-Coello P, Rind D, Devereaux PJ, Montori VM, Freyschuss B, Vist G, Jaeschke R, Williams JW Jr, Murad MH, Sinclair D, FalckYtter Y, Meerpohl J, Whittington C, Thorlund K, Andrews J, Schünemann HJ. GRADE 
guidelines 6. Rating the quality of evidence--imprecision. J Clin Epidemiol. 2011;64(12):1283-1293.

14. Guyatt GH OA, Kunz R, Woodcock J, Brozek J, Helfand M, Alonso-Coello P, Glasziou P, Jaeschke R, Akl EA, Norris S, Vist G, Dahm P, Shukla VK, Higgins J, Falck-Ytter Y, Schünemann HJ, GRADE Working Group. . GRADE guidelines: 7. Rating the quality of evidence--inconsistency. J Clin Epidemiol. 2011;64(12):1294-1302.

15. Guyatt GH OA, Kunz R, Woodcock J, Brozek J, Helfand M, Alonso-Coello P, FalckYtter Y, Jaeschke R, Vist G, Akl EA, Post PN, Norris S, Meerpohl J, Shukla VK, Nasser M, Schünemann HJ; GRADE Working Group. GRADE guidelines: 8. Rating the quality of evidence--indirectness. J Clin Epidemiol. 2011;64(12):1303-1310.

16. Guyatt GH OA, Sultan S, Glasziou P, Akl EA, Alonso-Coello P, Atkins D, Kunz R, Brozek J, Montori V, Jaeschke R, Rind D, Dahm P, Meerpohl J, Vist G, Berliner E, Norris S, Falck-Ytter Y, Murad MH, Schünemann HJ; GRADE Working Group. GRADE guidelines: 9. Rating up the quality of evidence. J Clin Epidemiol. 2011;64(12):1311-1316.

17. Rourke K, Hickle J. The clinical spectrum of the presenting signs and symptoms of anterior urethral stricture: Detailed analysis of a single institutional cohort. Urology. 2012;79(5):1163-1167.

18. King C, Rourke K. Urethral stricture is frequently a morbid condition: Incidence and factors associated with complications related to urethral stricture. Urology. 2019;132:189-194.

19. D'Elia A, Grossi FS, Barnaba D, et al. Ultrasound in the study of male urethral strictures. Acta Urol Ital. 1996;10(4):275-277.

20. El-Ghar MA, Osman Y, Elbaz E, Refiae H, El-Diasty T. MR urethrogram versus combined retrograde urethrogram and sonourethrography in diagnosis of urethral stricture. Eur J Radiol. 2010;74(3):e193-198.

21. Gupta S, Majumdar B, Tiwari A, Gupta RK, Kumar A, Gujral RB. Sonourethrography in the evaluation of anterior urethral strictures: correlation with radiographic urethrography. J Clin Ultrasound. 1993;21(4):231-239.

22. Kostakopoulos A, Makrychoritis K, Deliveliotis C, Nazlidou I, Picramenos D. Contribution of transcutaneous ultrasonography to the evaluation of urethral strictures. Int Urol Nephrol. 1998;30(1):85-89.

23. Mitterberger M, Christian G, Pinggera GM, et al. Gray scale and color Doppler sonography with extended field of view technique for the diagnostic evaluation of anterior urethral strictures. J Urol. 2007;177(3):992-996; discussion 997.

24. Osman Y, El-Ghar MA, Mansour O, Refaie H, El-Diasty T. Magnetic resonance urethrography in comparison to retrograde urethrography in diagnosis of male urethral strictures: Is it clinically relevant? Eur Urol. 2006;50(3):587-593.

25. Buckley JC HC, Gilling P, Carney J. SIU/ICUD consultation on urethral strictures: Dilation, internal urethrotomy, and stenting of male anterior urethral strictures. Urology. 2014;83:S18-22.

26. Morey AF WN, Shenfeld O, Eltahawy E, Giudice C. SIU/ICUD consultation on urethral strictures: Anterior urethra--primary anastomosis. Urology. 2014;83:S23-26. 
27. Chapple C AD, Atala A, Barbagli G, Cavalcanti A, Kulkarni S, Mangera A, Nakajima Y. SIU/ICUD consultation on urethral strictures: The management of anterior urethral stricture disease using substitution urethroplasty. Urology. 2014;83:S31-47.

28. Barbagli G DAM, Romano G, Lazzeri M. Clinical outcome and quality of life assessment in patients treated with perineal urethrostomy for anterior urethral stricture disease. J Urol. 2009;182(2):548-557.

29. Breyer BN ET, Patrick DL, Voelzke BB. Comprehensive qualitative assessment of urethral stricture disease: Toward the development of a patient centered outcome measure. J Urol. 2017;198(5):1113-1118.

30. Jackson MJ SJ, Mangera A, Brett A, Watkin N, N'dow JM, Chapple CR, Andrich DE, Pickard RS, Mundy AR. Defining a patient-reported outcome measure for urethral stricture surgery. Eur Urol. 2011;60(1):60-68.

31. Al Taweel W, Seyam R. Visual Internal Urethrotomy for Adult Male Urethral Stricture Has Poor Long-Term Results. Adv Urol. 2015;2015:656459.

32. Atak M, Tokgoz H, Akduman B, et al. Low-power holmium:YAG laser urethrotomy for urethral stricture disease: Comparison of outcomes with the cold-knife technique. Kaohsiung J Med Sci. 2011;27(11):503-507.

33. Barbagli G, Montorsi F, Balo S, et al. Treatments of 1242 bulbar urethral strictures: Multivariable statistical analysis of results. World Journal of Urology. 2018;15:15.

34. Cecen K, Karadag MA, Demir A, Kocaaslan R. PlasmaKineticTM versus cold knife internal urethrotomy in terms of recurrence rates: A prospective randomized study. Urologia Internationalis. 2014;93(4):460-463.

35. Choudhary AK, Jha NK. Is anastomotic urethroplasty is really superior than BMG augmented dorsal onlay urethroplasty in terms of outcomes and patient satisfaction: Our 4-year experience. Canadian Urological Association Journal. 2015;9(1-2):E22-E26.

36. Das RK, Basu S, Maity D, et al. Current clinical spectrum and management of stricture disease of urethra: A prospective study. Journal of Clinical and Diagnostic Research. 2017;11(11):PC01-PC04.

37. Ekeke ON, Amusan OE. Clinical presentation and treatment of urethral stricture: Experience from a tertiary hospital in Port Harcourt, Nigeria. African Journal of Urology. 2017;23(1):72-77.

38. Fall B, Sow Y, Diallo Y, et al. Urethroplasty for male urethral strictures: Experience from a national teaching hospital in Senegal. African Journal of Urology. 2014;20(2):76-81.

39. Holzhauer C, Roelofs AWTM, Kums AC, Weijerman PC, van Balken MR. Is the laser mightier than the sword? A comparative study for the urethrotomy. World journal of urology. 2018;36(4):663-666.

40. Hussein MM, Moursy E, Gamal W, Zaki M, Rashed A, Abozaid A. The use of penile skin graft versus penile skin flap in the repair of long bulbo-penile urethral stricture: A prospective randomized study. Urology. 2011;77(5):1232-1237.

41. Hyn CS, Jong KH, Chol CU. A report on the clinical efficacy of a new Bougie-internal urethrectomy. Canadian Urological Association Journal. 2015;9(7-8):E447-E452. 
42. Jain SK, Kaza RCM, Singh BK. Evaluation of holmium laser versus cold knife in optical internal urethrotomy for the management of short segment urethral stricture. Urology Annals. 2014;6(4):328-333.

43. Jhanwar A, Kumar M, Sankhwar SN, Prakash G. Holmium laser vs. conventional (cold knife) direct visual internal urethrotomy for short-segment bulbar urethral stricture: Outcome analysis. Canadian Urological Association Journal. 2016;10(5-6):E161-E164.

44. Kluth LA, Ernst L, Vetterlein MW, et al. Direct Vision Internal Urethrotomy for Short Anterior Urethral Strictures and Beyond: Success Rates, Predictors of Treatment Failure, and Recurrence Management. Urology. 2017;106:210-215.

45. Kulkarni S, Joshi P, Surana S, Hamouda A. Management of panurethral strictures. African Journal of Urology. 2016;22(1):33-39.

46. Kulkarni SB, Joshi PM, Venkatesan K. Management of panurethral stricture disease in India. J Urol. 2012;188(3):824-830.

47. Kunz I, Musch M, Vogel A, et al. Experience with One-Stage Repair of Urethral Strictures Using the Augmented Anastomotic Repair Technique. Urol Int. 2018;100(4):386-396.

48. Mandhani A, Chaudhury H, Kapoor R, Srivastava A, Dubey D, Kumar A. Can outcome of internal urethrotomy for short segment bulbar urethral stricture be predicted? J Urol. 2005;173(5):1595-1597.

49. Mazdak H, Izadpanahi MH, Ghalamkari A, et al. Internal urethrotomy and intraurethral submucosal injection of triamcinolone in short bulbar urethral strictures. Int Urol Nephrol. 2010;42(3):565-568.

50. Ozcan L, Polat EC, Otunctemur A, et al. Internal urethrotomy versus plasmakinetic energy for surgical treatment of urethral stricture. Archivio italiano di urologia, andrologia : organo ufficiale [di] Societa italiana di ecografia urologica e nefrologica / Associazione ricerche in urologia. 2015;87(2):161-164.

51. Pal D, Kumar S, Ghosh B. Direct visual internal urethrotomy: Is it a durable treatment option? Urology Annals. 2017;9(1):18-22.

52. Pansadoro V, Emiliozzi P. Internal urethrotomy in the management of anterior urethral strictures: Long-term followup. J Urol. 1996;156(1):73-75.

53. Redon-Galvez L, Molina-Escudero R, Alvarez-Ardura M, Otaola-Arca H, Alarcon Parra RO, Paez-Borda A. Predictors of urethral stricture recurrence after endoscopic urethrotomy. Actas Urol Esp. 2016;40(8):529-533.

54. Sachin D, ChikkaMoga Siddaiah M, Vilvapathy Senguttuvan K, Chandrashekar Sidaramappa R, Ramaiah K. Incidence of de novo erectile dysfunction after urethroplasty: A prospective observational study. World j. 2017;35(2):94-99.

55. Tinaut-Ranera J, Arrabal-Polo MA, Merino-Salas S, et al. Outcome of urethral strictures treated by endoscopic urethrotomy and urethroplasty. Canadian Urological Association Journal. 2014;8(1-2):E16-19.

56. Tolkach Y, Herrmann T, Merseburger A, et al. Development of a clinical algorithm for treating urethral strictures based on a large retrospective single-center cohort. F1000Res. 2016;5(2378):2378. 
57. Yenice MG, Seker KG, Sam E, et al. Comparison of cold-knife optical internal urethrotomy and holmium:YAG laser internal urethrotomy in bulbar urethral strictures. Central European Journal of Urology. 2018;71(1):114-120.

58. Yuruk E, Yentur S, Cakir OO, Ertas K, Serefoglu EC, Semercioz A. Catheter dwell time and diameter affect the recurrence rates after internal urethrotomy. Turkish $j$. 2016;42(3):184-189.

59. Janisch F, Abufaraj M, Fajkovic H, et al. Current disease management of primary urethral carcinoma. European Urology Focus. 2019;5(5):722-734.

60. Ekerhult TO, Lindqvist K, Peeker R, Grenabo L. Outcomes of reintervention after failed urethroplasty. Scand J Urol. 2017;51(1):68-72.

61. Sukumar S, Elliott SP, Myers JB, et al. Multi-institutional outcomes of endoscopic management of stricture recurrence after bulbar urethroplasty. Journal of Urology. 2018;200(4):837-842.

62. Vetterlein MW, Stahlberg J, Zumstein V, et al. The impact of surgical sequence on stricture recurrence after anterior 1-stage buccal mucosal graft urethroplasty:

Comparative effectiveness of initial, repeat and secondary procedures. Journal of Urology. 2018;03:03.

63. Rosenbaum CM, Schmid M, Ludwig TA, et al. Internal urethrotomy in patients with recurrent urethral stricture after buccal mucosa graft urethroplasty. World journal of urology. 2015;33(9):1337-1344.

64. Siegel JA, Panda A, Tausch TJ, Meissner M, Klein A, Morey AF. Repeat excision and primary anastomotic urethroplasty for salvage of recurrent bulbar urethral stricture. Journal of Urology. 2015;194(5):1316-1322.

65. Rosenbaum CM, Schmid M, Ludwig TA, et al. Redo buccal mucosa graft urethroplasty: Success rate, oral morbidity and functional outcomes. BJU International. 2016;118(5):797-803.

66. Mellon MJ, Bihrle R. Ventral onlay buccal mucosa urethroplasty: A 10-year experience. International Journal of Urology. 2014;21(2):190-193.

67. Levine MA, Kinnaird AS, Rourke KF. Revision urethroplasty success is comparable to primary urethroplasty: A comparative analysis. Urology. 2014;84(4):928-933.

68. Kahokehr AA, Granieri MA, Webster GD, Peterson AC. A critical analysis of bulbar urethroplasty stricture recurrence: Characteristics and management. Journal of Urology. 2018;03:03.

69. Farrell MR, Lawrenz CW, Levine LA. Internal urethrotomy with intralesional mitomycin C: An effective option for endoscopic management of recurrent bulbar and bulbomembranous urethral strictures. Urology. 2017;110:223-227.

70. Chapman D, Kinnaird A, Rourke K. Independent predictors of stricture recurrence following urethroplasty for isolated bulbar urethral strictures. Journal of Urology. 2017;198(5):1107-1112.

71. Cordon BH, Zhao LC, Scott JF, Armenakas NA, Morey AF. Pseudospongioplasty using periurethral vascularized tissue to support ventral buccal mucosa grafts in the distal urethra. Journal of Urology. 2014;192(3):804-807. 
72. Ekerhult TO, Lindqvist K, Peeker R, Grenabo L. Limited experience, high body mass index and previous urethral surgery are risk factors for failure in open urethroplasty due to penile strictures. Scandinavian Journal of Urology. 2015;49(5):415-418.

73. Fossati N, Barbagli G, Larcher A, et al. The surgical learning curve for one-stage anterior urethroplasty: A prospective single-surgeon study. European Urology. 2016;69(4):686-690.

74. Fuchs JS, Shakir N, McKibben MJ, et al. Changing trends in reconstruction of complex anterior urethral strictures: From skin flap to perineal urethrostomy. Urology. 2018;20:20.

75. Kizilay F, Simsir A, Ozyurt C. Analysis of recurrent urethral strictures due to iatrogenic urethral trauma. Turkish Journal of Medical Sciences. 2017;47(5):1543-1548.

76. Xu YM, Li C, Xie H, et al. Intermediate-term outcomes and complications of long segment urethroplasty with lingual mucosa grafts. Journal of Urology.

2017;198(2):401-406.

77. Heyns CF, Steenkamp JW, De Kock ML, Whitaker P. Treatment of male urethral strictures: Is repeated dilation or internal urethrotomy useful? J Urol. 1998;160(2):356358.

78. Ketabchi AA. Evaluation of combined electro cutter with cold knife in the intractable anterior urethral stricture urethrotomy. Journal of kerman university of medical sciences. 2017;24(6):487-497.

79. Rigatti P, Guazzoni G, Centemero A, Montorsi F, Consonni P, Bergamashi F. Endourethral prosthesis vs urethroplasty in the treatment of complex strictures of the bulbar urethra. Acta Urol Ital. 1993(1):51-54.

80. Viers BR, Pagliara TJ, Rew CA, et al. Urethral reconstruction in aging male patients. Urology. 2018;113:209-214.

81. Barbagli G, Kulkarni SB, Fossati N, et al. Long-term followup and deterioration rate of anterior substitution urethroplasty. Journal of Urology. 2014;192(3):808-813.

82. Welk BK, Kodama RT. The augmented nontransected anastomotic urethroplasty for the treatment of bulbar urethral strictures. Urology. 2012;79(4):917-921.

83. Barbagli G, Palminteri E, Lazzeri M, Guazzoni G, Turini D. Long-term outcome of urethroplasty after failed urethrotomy versus primary repair. J Urol. 2001;165(6 Pt 1):1918-1919.

84. Barbagli G, Morgia G, Lazzeri M. Dorsal onlay skin graft bulbar urethroplasty: longterm follow-up. Eur Urol. 2008;53(3):628-633.

85. Elgammal MA. Straddle injuries to the bulbar urethra: management and outcome in 53 patients. Int Braz J Urol. 2009;35(4):450-458.

86. Figler BD, Malaeb BS, Dy GW, Voelzke BB, Wessells H. Impact of graft position on failure of single-stage bulbar urethroplasties with buccal mucosa graft. Urology. 2013;82(5):1166-1170.

87. Kluth LA, Dahlem R, Reiss P, et al. Short-term outcome and morbidity of different contemporary urethroplasty techniques--a preliminary comparison. J Endourol. 2013;27(7):925-929.

88. Park S MJ. Straddle injuries to the bulbar urethra: management and outcomes in 78 patients. J Urol. 2004; 171:722-725. 
89. Doiron RC, Rourke K. An overview of urethral injury. Can Urol Assoc J. 2019;13:S6166.

90. Tausch TJ MA, Scott JF, Simhan J. Unintended negative consequences of primary endoscopic realignment for men with pelvic fracture urethral injuries. $J$ Urol. 2014;192(6):1720-1724.

91. MA E. Straddle injuries to the bulbar urethra: Management and outcome in 53 patients. Int Braz J Urol. 2009;35(4):450-458.

92. Mundy AR, Andrich D. Urethral trauma. Part II: Types of injury and their management. BJU Int. 2011;108(5):630-650.

93. Duel BP BJ, Gonzalez R. Management of urethral strictures after hypospadias repair. $J$ Urol. 1998;160(1):170-171.

94. Hoy NY, Rourke K. Better defining the spectrum of adult hypospadias: Examining the effect of childhood surgery on adult presentation. Urology. 2017;99:281-286.

95. Kozinn SI HN, Zinman L, Buckley JC. Management of complex anterior urethral strictures with multistage buccal mucosa graft reconstruction. Urology. 2013;82(3):718722.

96. Tang SH HC, Doumanian L, Santucci RA. Adult urethral stricture disease after childhood hypospadias repair. Adv Urol. 2008:150315.

97. Lumen N HP, Willemsen P, De Troyer B, Pieters R, Oosterlinck W. Etiology of urethral stricture disease in the 21st century. J Urol. 2009;182(3):983-987.

98. Barbagli G DAM, Palminteri E, Lazzeri M. Failed hypospadias repair presenting in adults. Eur Urol. 2006;49(5):887-894.

99. Ching CB WH, Ross JH, Gao T, Angermeier KW. The Cleveland Clinic experience with adult hypospadias patients undergoing repair: Their presentation and a new classification system. BJU Int. 2011;107(7):1142-1146.

100. Craig JR WC, Brant WO, Hotaling JM, Myers JB. Management of adults with prior failed hypospadias surgery. Transl Androl Urol. 2014;3(2):196-204.

101. Hensle TW TS, Reiley EA, Pollard J. Hypospadias repair in adults: Adventures and misadventures. J Urol. 2001;165(1):77-79.

102. Myers JB, McAninch JW, Erickson BA, Breyer BN. Treatment of adults with complications from previous hypospadias surgery. The Journal of urology. 2012;188(2):459-463.

103. Snodgrass W, Villanueva C, Bush N. Primary and reoperative hypospadias repair in adults: Are results different than in children? Journal of Urology. 2014;192(6):17301733.

104. Saavedra AA, Rourke K. Characterization and outcomes of urethroplasty for hypospadias-associated urethral strictures in adults. Can Urol Assoc J. 2019:E335E340.

105. Barbagli G PS, Djinovic R, Sansalone S, Lazzeri M. Retrospective descriptive analysis of 1,176 patients with failed hypospadias repair. J Urol. 2010;183(1):207-211.

106. Secrest CL JG, Winslow BH, Horton CE, McCraw JB, Gilbert DA, Devine CJ Jr. Repair of the complications of hypospadias surgery. J Urol. 1993;150:1415-1418. 
107. Primiceri G CP, Marchioni M, Schips L, Cindolo L. Bladder neck contracture after endoscopic surgery for benign prostatic obstruction: Incidence, treatment, and outcomes. Curr Urol Rep. 2017;18(10):79.

108. Elliott SP MM, Elkin EP, McAninch JW, Duchane J, Carroll PR; CaPSURE, Investigators. Incidence of urethral stricture after primary treatment for prostate cancer: Data from CaPSURE. J Urol. 2007;178(2):529-534.

109. Liberman D JS, Virnig BA, Chu H, Elliott SP. The patient burden of bladder outlet obstruction after prostate cancer treatment. J Urol. 2016;195(5):1459-1463.

110. Song J EJ, Brandes SB. Postprostatectomy anastomosis stenosis: A systematic review. Urology. 2015;86(2):211-218.

111. LaBossiere JR Cheung D, Rourke K. Endoscopic treatment of vesicourethral stenosis after radical prostatectomy: Outcomes and predictors of success. $J$ Urol. 2016;195(5):1495-1500.

112. Herschorn S ES, Coburn M, Wessells H, Zinman L. SIU/ICUD consultation on urethral strictures: Posterior urethral stenosis after treatment of prostate cancer. Urology. 2014;83:S59-70.

113. Redshaw JD BJ, Smith TG 3rd, Voelzke BB, Erickson BA, McClung CD, Elliott SP, Alsikafi NF, Presson AP, Aberger ME, Craig JR, Brant WO, Myers JB. Intralesional injection of mitomycin $\mathrm{C}$ at transurethral incision of bladder neck contracture may offer limited benefit: TURNS Study Group. J Urol. 2015;193(2):587-592.

114. Bugeja S AD, Mundy AR. Fistulation into the pubic symphysis after treatment of prostate cancer: An important and surgically correctable complication. J Urol. 2016;195(2):391-398.

115. Hindson BR MJ, Matheson B. Urethral strictures following high-dose-rate brachytherapy for prostate cancer: Analysis of risk factors. Brachytherapy. 2013;12(1):50-55.

116. Leapman MS SR, Stone NN, Hall SJ. Findings at cystoscopy performed for cause after prostate brachytherapy. Urology. 2014;83(6):1350-1355.

117. Merrick GS BW, Tollenaar BG, Galbreath RW, Lief JH. The dosimetry of prostate brachytherapy-induced urethral strictures. Int J Radiat Oncol Biol Phys. 2002;52(2):461-468.

118. Merrick GS BW, Wallner KE, Galbreath RW, Anderson RL, Allen ZA, Adamovich E. Risk factors for the development of prostate brachytherapy related urethral strictures. $J$ Urol. 2006;175(4):1376-1380.

119. Mundy AR, Andrich D. Posterior urethral complications of the treatment of prostate cancer. BJU Int. 2012;110(3):304-325.

120. Sullivan L WS, Tai KH, Foroudi F, Cleeve L, Duchesne GM. Urethral stricture following high dose rate brachytherapy for prostate cancer. Radiother Oncol. 2009;91(2):232-236.

121. Elliott SP MJ, Chi T, Doyle SM, Master VA. Management of severe urethral complications of prostate cancer therapy. J Urol. 2006;176:2508-2513.

122. Hofer MD ZL, Morey AF, Scott JF, Chang AJ, Brandes SB, Gonzalez CM. Outcomes after urethroplasty for radiotherapy induced bulbomembranous urethral stricture disease. J Urol. 2014;191(5):1307-1312. 
123. Meeks JJ, Brandes S, Morey AF, Thom M, Mehdiratta N, Valadez C, Granieri MA, Gonzalez CM. Urethroplasty for radiotherapy induced bulbomembranous strictures: A multi-institutional experience. J Urol. 2011;185(5):1761-1765.

124. Rourke K Kinnaird A, Zorn J. Observations and outcomes of urethroplasty for bulbomembranous stenosis after radiation therapy for prostate cancer. World J Urologia Internationalis. 2016;34(3):377-382.

125. Jiang R, Tomaszewski JJ, Ward KC, Uzzo RG, Canter DJ. The burden of overtreatment: Comparison of toxicity between single and combined modality radiation therapy among low risk prostate cancer patients. Can J Urol. 2015;22(1):7648-7655.

126. Hall EJ AM, Bedford J, Borek C, Curtis SB, Fry M, Geard C, Hei T, Mitchell J ON, et al. Basic radiobiology. Am J Clin Oncol. 1988;11(3):220-252.

127. MK T. Wound healing following radiation therapy: A review. Radiother Oncol. 1997;42(2):99-106.

128. Das S TH. Balanitis xerotica obliterans--a review. World J Urol. 2000;18(6):382-387.

129. Chung ASJ SO. Current treatment of lichen sclerosus and stricture. World J Urol. 2019.

130. Erickson BA ES, Myers JB, Voelzke BB, Smith TG 3rd, McClung CD, Alsikafi NF, Vanni AJ, Brant WO, Broghammer JA, Tam CA, Zhao LC, Buckley JC, Breyer BN; Trauma and Urologic Reconstructive Network of Surgeons. Understanding the relationship between chronic systemic disease and lichen sclerosus urethral strictures. $J$ Urol. 2016;195(2):363-368.

131. Pugliese JM MA, Peterson AC. Lichen sclerosus: Review of the literature and current recommendations for management. J Urol. 2007;178(6):2268-2276.

132. Potts BA BM, Peterson AC. Intraurethral steroids are a safe and effective treatment for stricture disease in patients with biopsy proven lichen sclerosus. $J$ Urol. 2016;195(6):1790-1796.

133. Venn SN MA. Urethroplasty for balanitis xerotica obliterans. Br J Urol. 1998;81(5):735-737.

134. Granieri MA PA, Madden-Fuentes RJ. Effect of lichen sclerosis on success of urethroplasty. Urol Clin North Am. 2017;44(1):77-86.

135. Kulkarni S BG, Kirpekar D, Mirri F, Lazzeri M. Lichen sclerosus of the male genitalia and urethra: Surgical options and results in a multicenter international experience with 215 patients. Eur Urol. 2009;55(4):945-954. 
Figures and Tables

\begin{tabular}{|c|c|c|}
\hline Implications & Strong recommendation & Conditional recommendation \\
\hline For patients & $\begin{array}{l}\text { Most individuals in this situation } \\
\text { would want the recommended } \\
\text { course of action, and only a small } \\
\text { proportion would not. } \\
\text { Formal decision aids are not likely } \\
\text { to be needed to help individuals } \\
\text { make decisions consistent with their } \\
\text { values and preferences. }\end{array}$ & $\begin{array}{l}\text { Most individuals in this situation would } \\
\text { want the suggested course of action, but } \\
\text { many would not. }\end{array}$ \\
\hline $\begin{array}{l}\text { For } \\
\text { clinicians }\end{array}$ & $\begin{array}{l}\text { Most individuals should receive the } \\
\text { recommended course of action. } \\
\text { Adherence to this recommendation } \\
\text { according to the guidelines could be } \\
\text { used as a quality criterion or } \\
\text { performance indicator. }\end{array}$ & $\begin{array}{l}\text { Clinicians should recognize that different } \\
\text { choices will be appropriate for each } \\
\text { individual and that clinicians must help } \\
\text { each individual arrive at a management } \\
\text { decision consistent with the individual's } \\
\text { values and preferences. } \\
\text { Decision aids may be useful to help } \\
\text { individuals make decisions consistent with } \\
\text { their values and preferences. }\end{array}$ \\
\hline $\begin{array}{l}\text { For policy- } \\
\text { makers }\end{array}$ & $\begin{array}{l}\text { The recommendation can be adopted } \\
\text { as policy in most situations. }\end{array}$ & $\begin{array}{c}\text { Policy-making will require substantial } \\
\text { debate and involvement of various } \\
\text { stakeholders. }\end{array}$ \\
\hline
\end{tabular}

\begin{tabular}{|c|c|c|c|c|c|c|}
\hline \multicolumn{5}{|c|}{$\begin{array}{l}\text { Table 2: Test accuracy data for RUG and } \\
\text { SUG based on } 40 \% \text { and } 60 \% \text { prevalence of } \\
\text { urethral stricture by clinical suspicion }\end{array}$} & & \\
\hline \multicolumn{2}{|c|}{ Urethrogram: RUG } & \multicolumn{3}{|c|}{ Urethrogram: SUG } & & \\
\hline Sensitivity & 0.94 & Sen & vity & 0.90 & & \\
\hline Specificity & 0.90 & Spe & city & 1.00 & & \\
\hline \multirow{3}{*}{ Outcome } & \multicolumn{6}{|c|}{ Effect per 100 patients tested } \\
\hline & \multicolumn{4}{|c|}{ Pre-test probability of $60 \%$} & \multicolumn{2}{|c|}{ Pre-test probability of $40 \%$} \\
\hline & \multicolumn{2}{|c|}{$\begin{array}{l}\text { Urethrogram: } \\
\text { RUG }\end{array}$} & \multicolumn{2}{|c|}{$\begin{array}{l}\text { Urethrogram: } \\
\text { SUG }\end{array}$} & Urethrogram: RUG & $\begin{array}{l}\text { Urethrogram: } \\
\text { SUG }\end{array}$ \\
\hline
\end{tabular}




\begin{tabular}{|l|l|l|l|l|}
\hline \multirow{2}{*}{$\begin{array}{l}\text { True } \\
\text { positives }\end{array}$} & $56(0-0)$ & $54(0-0)$ & $38(0-0)$ & $36(0-0)$ \\
\cline { 2 - 5 } & 2 more TP in urethrogram: RUG & 2 more TP in urethrogram: RUG \\
\hline \multirow{2}{*}{$\begin{array}{l}\text { False } \\
\text { negatives }\end{array}$} & $4(60-60)$ & $6(60-60)$ & $2(40-40)$ & $4(40-40)$ \\
\cline { 2 - 5 } & 2 fewer FN in urethrogram: RUG & 2 fewer FN in urethrogram: RUG \\
\hline \multirow{2}{*}{$\begin{array}{l}\text { True } \\
\text { negatives }\end{array}$} & $36(0-0)$ & $40(0-0)$ & $54(0-0)$ & $60(0-0)$ \\
\cline { 2 - 5 } & 4 fewer TN in urethrogram: RUG & 6 fewer TN in urethrogram: RUG \\
\hline $\begin{array}{l}\text { False } \\
\text { positives }\end{array}$ & $4(40-40)$ & $0(40-40)$ & $6(60-60)$ & $0(60-60)$ \\
\cline { 2 - 5 } & 4 more FP in urethrogram: RUG & 6 more FP in urethrogram: RUG \\
\hline
\end{tabular}

\section{Table 3. Clinically important outcomes}

Improvement in lower urinary tract symptoms

Health-related quality of life

Need for further procedures

Complications (stricture and treatment related)

Sexual dysfunction

Genitourinary pain 
Table 4. Benefits and harms of endoscopic management vs. urethroplasty of urethral stricture

\begin{tabular}{|c|c|c|c|c|c|c|}
\hline \multirow[b]{2}{*}{$\begin{array}{l}\text { Outcomes } \\
\text { Number of participants } \\
\text { (studies) }\end{array}$} & \multirow[b]{2}{*}{$\begin{array}{l}\text { Certainty } \\
\text { of the } \\
\text { evidence } \\
\text { (GRADE) }\end{array}$} & \multicolumn{2}{|c|}{ Study event rates } & \multirow[b]{2}{*}{$\begin{array}{l}\text { Relative } \\
\text { effect } \\
(95 \% \text { CI })\end{array}$} & \multicolumn{2}{|c|}{ Anticipated absolute effects } \\
\hline & & $\begin{array}{c}\text { With } \\
\text { urethroplasty }\end{array}$ & $\begin{array}{c}\text { With } \\
\text { endoscopic } \\
\text { management } \\
\text { (dilation or } \\
\text { DVIU) }\end{array}$ & & $\begin{array}{c}\text { Risk with } \\
\text { urethroplasty }\end{array}$ & $\begin{array}{l}\text { Risk difference with } \\
\text { endoscopic management } \\
\text { (dilation or DVIU) }\end{array}$ \\
\hline $\begin{array}{l}\text { Stricture recurrence - Comparative } \\
1655 \\
(5 \text { observational studies })^{1-5}\end{array}$ & $\begin{array}{l}\oplus \bigcirc \bigcirc \bigcirc \\
\text { VERY } \\
\text { LOW }\end{array}$ & $\begin{array}{c}231 / 1103 \\
(20.9 \%)\end{array}$ & $\begin{array}{l}189 / 552 \\
(34.2 \%)\end{array}$ & $\begin{array}{c}\text { RR } 2.19 \\
(1.46- \\
3.27)\end{array}$ & 209 per 1000 & $\begin{array}{c}249 \text { more per } \mathbf{1 0 0 0} \\
(96 \text { more to } 475 \text { more })\end{array}$ \\
\hline $\begin{array}{l}\text { Complications - Initial \& recurrent stricture - } \\
\text { Comparative } \\
193 \\
(1 \text { observational study })^{2}\end{array}$ & $\bigoplus \mathrm{VEF}$ & $\begin{array}{c}8 / 95 \\
(8.4 \%)\end{array}$ & $12 / 98(12.2 \%)$ & $\begin{array}{l}\text { RR 1.45 } \\
(0.62- \\
3.40)\end{array}$ & 84 per 1000 & $\begin{array}{c}38 \text { more per } 1000 \\
\text { (32 fewer to } 202 \text { more) }\end{array}$ \\
\hline $\begin{array}{l}\text { Stricture recurrence }- \text { Non-comparative } \\
2616 \\
(22 \text { observational studies })^{6-27}\end{array}$ & $\begin{array}{l}\oplus \bigcirc \bigcirc \bigcirc \\
\text { VERY } \\
\text { LOW }\end{array}$ & $\begin{array}{l}87 / 563 \\
(15.5 \%)\end{array}$ & $\begin{array}{l}790 / 2053 \\
(38.5 \%)\end{array}$ & $\begin{array}{c}\text { Not } \\
\text { pooled }\end{array}$ & Not pooled & Not pooled \\
\hline
\end{tabular}




\begin{tabular}{|c|c|c|c|c|c|c|}
\hline $\begin{array}{l}\text { Quality of Life (post-op scores) - Non } \\
\text { comparative } \\
60 \\
(1 \text { observational study })^{8}\end{array}$ & $\begin{array}{l}\oplus \bigcirc \bigcirc \bigcirc \\
\text { VERY } \\
\text { LOW }\end{array}$ & - & & - & Not pooled & Not pooled \\
\hline $\begin{array}{l}\text { Complications - Non-comparative } \\
1976 \\
(9 \text { observational studies })^{6,7,9,11,12,17,18,19,28}\end{array}$ & $\begin{array}{l}\oplus \bigcirc \bigcirc \bigcirc \\
\text { VERY } \\
\text { LOW }\end{array}$ & $87 / 622(14.0 \%)$ & $\begin{array}{c}32 / 1354 \\
(2.4 \%)\end{array}$ & $\begin{array}{c}\text { Not } \\
\text { pooled }\end{array}$ & Not pooled & Not pooled \\
\hline
\end{tabular}

CI: confidence interval; DIVU: direct visual internal urethrotomy; RR: relative risk. 


\begin{tabular}{|c|c|c|c|}
\hline \multirow[b]{2}{*}{ Complication } & \multirow[b]{2}{*}{$\begin{array}{c}\text { No of participants } \\
\text { (studies) }\end{array}$} & \multicolumn{2}{|c|}{ Study event rates (\%) } \\
\hline & & With urethroplasty & $\begin{array}{c}\text { With endoscopic } \\
\text { management } \\
\text { (dilation or DVIU) }\end{array}$ \\
\hline Erectile dysfunction & 130 (2 studies) & $26 / 130(20.0 \%)$ & - \\
\hline Urinary incontinence & 90 (1 study) & $9 / 90(10.0 \%)$ & - \\
\hline Other urinary & 348 (5 studies) & $25 / 127(19.7 \%)$ & $1 / 221(0.5 \%)$ \\
\hline Infection & 331 (4 studies) & $4 / 37(10.8 \%)$ & $2 / 294(0.7 \%)$ \\
\hline Bleeding & 405 (6 studies) & $5 / 37(13.5 \%)$ & $15 / 368(4.1 \%)$ \\
\hline Fluid extravasation & 152 (2 studies) & 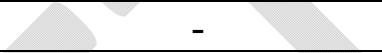 & $9 / 152(5.9 \%)$ \\
\hline Swelling & 37 (1 study) & $12 / 37(32.4 \%)$ & - \\
\hline Fistula complications & 37 (1 study) & $1 / 37(2.7 \%)$ & - \\
\hline Overall/any & 132 (1 study) & - & $5 / 132(3.8 \%)$ \\
\hline Other & 314 (4 studies) & $5 / 127(3.9 \%)$ & $0 / 187(0.0 \%)$ \\
\hline
\end{tabular}

DIVU: direct visual internal urethrotomy. 


\begin{tabular}{|c|c|c|c|c|c|c|}
\hline \multirow[b]{2}{*}{$\begin{array}{l}\text { Outcomes } \\
\text { Number of } \\
\text { participants } \\
\text { (studies) }\end{array}$} & \multirow[b]{2}{*}{$\begin{array}{c}\text { Certainty of } \\
\text { the evidence } \\
\text { (GRADE) }\end{array}$} & \multicolumn{2}{|c|}{ Study event rates } & \multirow[b]{2}{*}{$\begin{array}{c}\text { Relative } \\
\text { effect } \\
(95 \% \text { CI })\end{array}$} & \multicolumn{2}{|c|}{ Anticipated absolute effects } \\
\hline & & $\begin{array}{c}\text { With } \\
\text { endoscopic } \\
\text { management } \\
\text { (dilation or } \\
\text { DVIU) }\end{array}$ & $\begin{array}{c}\text { With } \\
\text { urethroplasty }\end{array}$ & & $\begin{array}{l}\text { Risk with } \\
\text { endoscopic } \\
\text { management } \\
\text { (dilation or } \\
\text { DVIU) }\end{array}$ & $\begin{array}{c}\text { Risk difference } \\
\text { with } \\
\text { urethroplasty }\end{array}$ \\
\hline $\begin{array}{l}\text { Stricture - } \\
\text { Comparative } \\
179 \\
\text { ( } 1 \text { observational } \\
\text { study) } 60\end{array}$ & $\begin{array}{c}\oplus \bigcirc \bigcirc \bigcirc \\
\text { VERY LOW }\end{array}$ & $92 / 124(74.2 \%)$ & $30 / 55$ & $\begin{array}{c}\text { RR 0.74 } \\
(0.57- \\
0.96)\end{array}$ & 74 per 100 & $\begin{array}{c}19 \text { fewer per } 100 \\
\text { (from } 32 \text { fewer to } \\
3 \text { fewer) }\end{array}$ \\
\hline $\begin{array}{l}\text { Stricture - Non- } \\
\text { comparative } \\
4408 \\
\text { ( } 31 \text { observational } \\
\text { studies) })^{44,48,51,61-88}\end{array}$ & $\begin{array}{r}\oplus C \\
\text { VER }\end{array}$ & $\begin{array}{l}306 / 623 \\
(49.1 \%)\end{array}$ & $\begin{array}{c}603 / 3785 \\
(15.9 \%)\end{array}$ & Not pooled & Not pooled & Not pooled \\
\hline $\begin{array}{l}\text { Complications } \\
\text { (counts) } \\
681 \\
\text { ( } 11 \text { observational } \\
\text { studies })^{60,63,65-67,} \\
69,76,78,79,82,86\end{array}$ & $\begin{array}{c}\oplus \bigcirc \bigcirc \bigcirc \\
\text { VERY LOW }\end{array}$ & $\begin{array}{l}47 / 174 \\
(27.0 \%)\end{array}$ & $\begin{array}{l}133 / 507 \\
(26.0 \%)\end{array}$ & Not pooled & Not pooled & Not pooled \\
\hline
\end{tabular}

DIVU: direct visual internal urethrotomy. 


\begin{tabular}{|l|c|c|c|}
\hline \multicolumn{4}{|l|}{$\begin{array}{l}\text { Table 7. Benefits of urethroplasty versus endoscopic management for recurrent } \\
\text { strictures by prior baseline characteristics }\end{array}$} \\
\hline Study or subgroup & $\begin{array}{c}\text { No of participants } \\
\text { (studies) }\end{array}$ & $\begin{array}{c}\text { With endoscopic } \\
\text { management } \\
\text { (dilation or DVIU) }\end{array}$ & With urethroplasty \\
\cline { 2 - 4 } & 1671 (14 studies) & $192 / 386(50 \%)$ & $137 / 1285(11 \%)$ \\
\hline $\begin{array}{l}\text { Prior endoscopy } \\
\text { (DVIU and/or } \\
\text { dilation) }\end{array}$ & 625 (12 studies) & $149 / 241(62 \%)$ & $75 / 384(20 \%)$ \\
\hline Prior Urethroplasty & & & \\
\hline
\end{tabular}

*Patients may have had multiple previous procedures (multiple previous endoscopies with or without prior urethroplasty). DIVU: direct visual internal urethrotomy.

\begin{tabular}{|c|c|c|c|}
\hline \multirow[b]{2}{*}{ Complication } & \multirow[b]{2}{*}{$\begin{array}{c}\text { No of participants } \\
\text { (studies) }\end{array}$} & \multicolumn{2}{|c|}{ Study event rates $(\%)$} \\
\hline & & $\begin{array}{c}\text { With endoscopic } \\
\text { management } \\
\text { (dilation or DVIU) }\end{array}$ & With urethroplasty \\
\hline Erectile dysfunction & 206 (3 studies) & - & $34 / 206(17 \%)$ \\
\hline UTI & 241 (4 studies) & $18 / 130(14 \%)$ & $10 / 111(9.0 \%)$ \\
\hline Urinary incontinence & 245 (4 studies) & $6 / 43(14 \%)$ & $17 / 202(8.4 \%)$ \\
\hline Bleeding & 168 (2 studies) & $6 / 87(6.9 \%)$ & $0 / 81(0 \%)$ \\
\hline Extravasation & 87 (1 study) & $10 / 87(11 \%)$ & - \\
\hline Fistula complications & 227 (3 studies) & - & $19 / 227(8.4 \%)$ \\
\hline Diverticulum & 210 (2 studies) & - & $5 / 210(2.4 \%)$ \\
\hline
\end{tabular}

DIVU: direct visual internal urethrotomy; UTI: urinary tract infection. 